\title{
Salinger and Holden: Silent Heroes of Modern Times
}

\author{
Parvin Ghasemi \\ Department of Foreign Languages and Linguistics, Faculty of Humanities and \\ Literature, Shiraz University, Eram Campus, Eram St. 7194684795, Shiraz, Iran \\ e-mails: pghasemi2000@yahoo.com; pghasemi54@gmail.com \\ Masoud Ghafoori \\ Department of Translation, Faculty of Humanities and Literature, Payame Noor \\ University of Evaz, Sharhdari Blvd. Evaz, Iran \\ e-mails: masoud17@gmail.com
}

\begin{abstract}
Among the great writers of the tumultuous decade of 1950s America, J. D. Salinger acquires a peculiar stance. His popularity rests precisely on two bases: that he was the writer of one literary bible of the young generations to come, The Catcher in the Rye, and that he was, ironically enough, resentful toward the publicity brought by this novel and few, but brilliant, short stories. This essay will focus on the mystery of Salinger's silence and self-imposed exile by exploring his life and ideas and the various social and critical responses to his celebrated novel.
\end{abstract}

Key words: silent heroes, modern times, silence and self-imposed exile, critical responses

Today, over 50 years since its publication, The Catcher in the Rye is undoubtedly one of the most read and most acclaimed works of American literature. Millions of readers from distant places and times have identified with Holden Caulfield and have roamed with him in the city of New York. The novel has gone through seventy printings, has sold over sixty million copies, and has been translated into thirty languages. "A 1998 poll by the Board of the Modern Library places Catcher at Number 64 in its list of the 100 best novels in English, while its companion readers' poll places the novel at Number 19. In 2003 the BBC's 'Big Read' campaign ranked Catcher at Number 15 in a nationwide poll of favorite novels" (Graham, 2007, p. xi). Catcher soon became a must-read novel for all, especially for the young, and turned into a cultural icon in the U.S. As Steinle (2000) argues in her In Cold Fear: The Catcher in the Rye Censorship 
Controversies and Postwar American Character, Catcher is "more than a novel: it is a 'cultural statement', a text that can be claimed by any generation, that echoes through many other texts; a novel that can even change its reader" (as quoted in Graham, 2007, p. 66).

Upon noticing the influence of this tragicomic story on its readers, French (1970) makes use of the term "Age of Salinger" for the period between 1948 and 1959 -publication dates of Salinger's A Perfect Day for Bananafish and Seymour: An Introduction, respectively- for, he believes, "these dates are important in discussing the rage for Salinger, because not since the enthusiasm during the early Romantic period for Goethe's young Werther had fictional characters so completely dominated the imaginative fancies of a decade as Seymour Glass and Holden Caulfield dominated the dim, defensive 50s" (p. 514).

But the immense popularity of the novel and the applause of the critics did not affect its author, J. D. Salinger. Or better to say, he did not want it. Soon after Catcher was published, Salinger withdrew from the public, took leave of New York -the city he was born and raised in- and went to a self-imposed exile in the rather rural setting of Cornish, New Hampshire since 1953. He published a few short stories afterwards, and the rest, since 1965, was silence. Pattanaik (1998) speaks of Salinger's silence as though it is another one of his works. The interpretation and decoding of this last "work" is, no doubt, crucial in understanding Salinger and his other works. This essay will undertake this difficult task by referring first to Salinger's biography and then to his novel in discussion, The Catcher in the Rye.

\section{J. D. SALINGER: THE SILENT WRITER}

Jerome David Salinger was born on the first day of the year 1919 to a fairly well-to-do family in New York City. His father, Solomon (Sol) was Jewish. He had a successful career working for a company that imported meat and cheese from Europe. His mother, Miriam, was an Irish Catholic, but changed her name to Marie to appease Sol's family. His older sister was named Doris.

Sonny -for that was his nickname in the family- had a cold and distant relationship with his father, "and he did not even bother to attend his funeral" (Morrill, 2006, p. 161). For one thing, he hated his father's business. When he was young, his father sent him to Poland to see first hand the other side of the business, and he was so repulsed by the sight of 
slaughterhouses that he decided to embark on a totally different career right away (p. 164). This disgust can also be responsible for his vegetarianism as an adult. Salinger, who always incorporates his own life and experiences in his fiction, reflects this semi-traumatic side of his family life in almost all his stories: in both Caulfield and Glass families there is a meaningful absence of father, and the older brothers -Seymour and Buddy in Glass family, D. B. in Caulfield family- assume the role of the father. And perhaps it is as a result of this absence that Salinger himself did not manage to become a very successful father, as his daughter, Margaret, bears testimony in her memoir, Dream Catcher: A Memoir (Salinger, 2000).

His relationship with his mother, though, was more affectionate. She was a source of mental conflict, as obviously reflected again in his stories about the Caulfield and Glass family. Though mothers do not occupy a central role in these families, their presence provokes an intense sense of tension and conflict, sometimes even provides them with rare epiphanic moments. The dedication page of Catcher reads: To My Mother (Salinger, 1958). Although Holden's closest encounter with his mother is hearing her voice once in the whole narrative, he describes her on different occasions as touchy, nervous and caring; he says: "Mothers are all slightly insane" (Salinger, 1958, p. 68). His mind is so occupied by the image of his mother that he tries to find a mother figure -both Good and Terrible Mother- in many of the girls and women he encounters. And in the case of Glass stories, this epiphanic scene that happens for Zooey best demonstrates the influence of the mother in this family:

Zooey turned full around to look at his mother. He turned around and looked at her, in this instance, in precisely the same way that, at one time or another, in one year or another, all his brothers and sisters (and especially his brothers) had turned around and looked at her. Not just with objective wonder at the rising of a truth, fragmentary or not, up through what often seemed to be an impenetrable mass of prejudices, clichés, and bromides. But with admiration, affection, and, not least, gratitude. And, oddly or not, Mrs. Glass invariably took this 'tribute', when it came, in beautiful stride. She would look back with grace and modesty at the son or daughter who had given her the look. She now presented this gracious and modest countenance to Zooey (Salinger, 1962, pp. 98-99). 
The issue of family is, after all, a very serious question in the fiction of Salinger, as it is in many other fictions dealing with urban life of the twentieth century.

Just after Salinger was born, his family moved from northern Harlem to $113^{\text {th }}$ Street. They later on moved first to West $82^{\text {nd }}$ Street and finally to Park Avenue, "all intentionally chosen by his father," as Curry (2007) believes, "to 'elevate' the family to more affluent white neighbourhoods" (p. 82). He failed to do well in school and was enrolled at Valley Forge Military Academy in Pennsylvania, much the same as described in Catcher.

His failures in school -and perhaps in establishing a close relationship with his father-was partly a result of his anxiety and confusion over his mixed religion. He was half-Jewish and half-Christian, which brought him intense mental confusion, especially in the 1920s and 1930s that antiSemitism was an open and powerful trend in American society. His sister, Doris, is reported to have said: "It wasn't nice to be half-Jewish in those days. It was no asset to be Jewish either, but at least you belonged somewhere" (Mondloch, 2003, p. 234). This is another traumatic experience that Salinger reflects in his stories. Both Glass and Caulfield children have mixed religions: Glasses are, exactly like Salinger himself, half-Jewish and half-Catholic; and Holden justifies his atheism by saying that "my parents are different religions, and all the children in our family are atheists" (Salinger, 1965, pp. 119-120). He reveals that "my father was a Catholic once. He quit, though, when he married my mother" (p. 134).

Salinger graduated with a respectable record from the Military Academy in 1936 and then attended New York University briefly. In 1939, he enrolled in an evening class in creative writing at Columbia University. This class was audited by Whit Burnett, the editor of Story, the magazine which would be the first to publish a short story by Salinger, The Young Folks, in 1940. Burnett was so pleased by this story -which is a description of some young people in a party who are not enjoying the party and do not like each other much- that he published it without any change. Over the next two years, Salinger wrote and published short stories in major magazines.

At the same time, when Europe was involved in the Second World War, the enthusiastic and patriotic Salinger attempted for several times to enlist in the army, all in vain. Eventually, when U.S. entered the War, Salinger found himself eligible for the draft. In April 1942, at the age of 23, 
he entered the army and was sent to the Europe theatre. Though he acted bravely in the war and won some medals, his disillusionment with the realities of war is obvious in his stories of this period. Salinger was trained for counter-intelligence, participated in some of the most brutal battles of the Second World War, such as the notorious Allied attack on Normandy in June 1944 known as D-Day, and witnessed the death of many of his comrades. He was eventually hospitalized at the end of the war in 1945 because of a nervous breakdown.

The influence of the war experience on Salinger cannot be easily overstated. Margaret recalls her father saying: "You never really get the smell of burning flesh out of your nose entirely no matter how long you live" (Salinger, 2000, p. 55). This traumatic experience is no doubt one of the strongest themes that relates Salinger's stories to each other. Most significant representations of war in his short stories appear in A Perfect Day for Bananafish (1948) in which Seymour Glass -later to become the Guru of the family- appears as a war veteran who commits suicide in a hotel room next to his sleeping wife; and in another short story, For Esméwith Love and Squalor (1950) in which we find Sergeant X hospitalized because of battle fatigue after D-Day. Though in Catcher no bullet is shot and no bomb explodes, war is present in the background and the overtone of the narrative reveals a deep hatred towards the Army and the war. Holden has learned a lot about war from his brother D.B.:

My brother D.B. was in the Army for four goddamn years. He was in the war too -he landed on D-Day and all- [one cannot miss the similarity between D.B. and Salinger here] but I really think he hated the Army worse than the war .... He said the Army was practically as full of bastards as the Nazis were (Salinger, 1958, pp. 166-167).

Holden exhibits his utmost disgust towards war by saying: "Anyway, I'm sort of glad they've got the atomic bomb invented. If there's ever another war, I'm going to sit right the hell on top of it. I'll volunteer for it, I swear to God I will" (p. 168).

Salinger came back from Europe with a handful of raw material for writing and a wife, Sylvia. The marriage lasted only a few months. His second marriage with Claire Douglas In 1955 ended in divorce again in 1967. A girl (Margaret, born in 1955) and a boy (Matthew, born in 1960) were the fruits of this marriage. There are a lot of stories about Salinger's 
affairs with other women, mostly very young actors. Most famous is his two-year relationship, from 1972 to 1973, with Joyce Maynard, an eighteen year old magazine writer at the time, who eventually published a memoir of her time with him in 1998 entitled At Home in the World. Very little is known about his third wife, Colleen O'Neill, whom he married in the late 1980s.

As early as 1941 Salinger was thinking about Holden. "In 1941 Salinger wrote to a friend that he was also working on a novel, 'a portrait of himself when young' that would become Catcher" (Graham, 2007, p. 4). In fact, "Slight Rebellion off Madison" which was purchased by The New Yorker in the same year but published five years later in December 1945, features a prototype of Holden in Catcher. This short story is written in third person point of view and relates Holden's dating with his girlfriend, Sally. Salinger's last published story of 1945, I'm Crazy in Collier's is also narrated by the teenage Holden Caulfield: He begins with his visit to Mr. Spencer, then he goes home to have a talk with his two sisters, Phoebe and Viola, and finally falls asleep while thinking about the ducks in Central Park.

As Salzman (1993) contends, in line with many other critics, "it was not until the publication of 'Bananfish' itself, in The New Yorker on January 31, 1948, that Salinger's stories began to show the consummate artistry that would make his fiction among the most significant produced by a writer in the post-World War II generation" (p. 4). The New Yorker was his publisher from then on in which a number of his best stories appeared: Uncle Wiggily in Connecticut (March 1948), Just Before the War with the Eskimos (June 1948), The Laughing Man (March 1949), For Esmé -with Love and Squalor (April 1950), and Pretty Mouth and Green My Eyes (July 1951).

Surprisingly, The New Yorker declined to run an excerpt of Catcher in 1951. The editors of the magazine told Salinger that "the precocity of the four Caulfield children was not believable, and that the writing was showoffy" (Menand, 2006, p. 235). The novel was finally published by Little, Brown in July 1951 and enjoyed an enormous success. The influential Book-of-the-Month Club selected it as its main selection for July, and Fadiman wrote on behalf of the Club: "That rare miracle of fiction has again come to pass: a human being has been created out of ink, paper, and the imagination" (as quoted in Salzman, 1993, p. 4). "Within two weeks, [Salinger's novel] had been reprinted five times, the next month 
three more times.... His book stayed on the bestseller list for thirty weeks, though never above fourth place" (Whitfield, 1997, p. 567). Later on, when it appeared in paperback, "the novel sold over three million copies between 1953 and 1964, climbed even higher by the 1980s, and continues to attract about as many buyers as it did in 1951. The durability of its appeal is astonishing. The Catcher in the Rye has gone through over seventy printings and has spread into thirty languages" (pp. 567-68).

Salinger's reputation and popularity rose overnight, and he turned out to become the center of attention of the public and the mass media. But it soon became clear that he shunned publicity and craved for his privacy. He even wanted his photograph to disappear from the jacket of the novel by the third edition. When the pressure of the market and the mass media heightened, he was forced to move to Tarrytown, New York, and then to Westport, Connecticut. The red brick house in Cornish, New Hampshire, was his last refuge since 1953. In the first months of his residence in Cornish, Salinger warmly befriended a group of students at Windsor High School. Shirlie Blaney, one of these kids who at the age of 16 interviewed Salinger for their school journal, Daily Eagle, remembers how their teenage parties at Salinger's house was fun and how Jerry -for that was Salinger's nickname then- "was just like one of the gang" (Havermann, 1961, p. 12). But Salinger soon discovered the threat of this intimacy to his privacy, and practically shut his door to the entire world.

He nevertheless continued writing and publishing short stories, mostly about the Glass family, and mostly in The New Yorker. He published Franny -sometimes considered as a female Holden- in January 1955, and a few months later, in November, Raise High the Roof Beam, Carpenters. This latter story, which is the story of Seymour's marriage, is narrated through the voice of the second older brother, Buddy, who is usually compared with Salinger himself because of his reclusion in an outof-town cottage and his tendency towards living a meditative life. Zooey was published a year and a half later, in May 1957, introducing another progeny in the Glass family. Two years later Salinger deployed Buddy's voice to complete the image of the memorable older brother, Seymour, in Seymour: An Introduction.

Salinger did not publish any new story until 1965. In September 1961, though, Franny and Zooey was published, and "within two weeks, 125,000 copies had been sold, and for six months the thin volume remained on the New York Times best-seller list" (Salzman, 1993, p. 7). This was followed in 1963 by the publication in one volume of two other previously published 
stories, Raise High the Roof Beam, Carpenters and Seymour: An Introduction. When Salinger published Hapworth 16, 1924 in The New Yorker in June 1965, he shocked his avid readers by the seemingly endless letter which the seven-year-old Seymour sends home from a camp. The story found little critical favor, and prompted Salinger to withdraw to his cherished recluse, never to publish another story or to appear in public any more.

Reactions to Salinger's silence have been various. Some say he was continuing publishing stories under various pseudonyms. One interesting case was an essay by Batchelor (1976), in which the fanciful author claimed that Pynchon is not a real name and the writer of his stories "is Jerome David Salinger" (Alexander, 2000, p. 188). Some others believe that his stories are for a good part autobiographical, and since he had exploited his life and experiences fully, there was not much left to write about. Some others, in search for a more serious explanation, note that there is a gradual shrinking of theme, setting and language in Salinger's stories -from traditional quest narrative to a more mystical internal quest, and from Holden's slang to the solipsistic language of later stories; and that this shrinking eventuated an inevitable silence. As Pattanaik (1998) reports, Hassan (1982) in The Dismemberment of Orpheus provides a more thoughtful explanation when he places Salinger in what he calls "literary tradition of silence", including such figures as de Sade, the Dadaists, the Surrealists and authors like Hemingway, Kafka, Camus, and Beckett, and observes that "silence in these authors ... is used as a metaphor for all kinds of negative stances -anti-literature, alienation from reason and nature and creation of anti-language" (p. 200).

Yet perhaps the most fitting explanation -and most relevant to this paper - comes from Salinger's study of Eastern philosophy as a result of his sense of lost religion. Mondloch (2003) refers to this sense of loss as one of the most influential factors in Salinger's life as an adult (she notes that the important factor in his childhood was his half-Jewishness, and in youth, his war experiences) (p. 235). Salinger created an idiosyncratic religion which embraced a pluralistic combination of Christian mysticism and Eastern spiritualities like Advaida Vedanta, Taoism, an ancient Chinese religion, and most prominently, Zen-Buddhism. This kind of individualistic religion is perhaps the most important theme which illuminates and links his stories. As Harper (1967) notes in Desperate Faith, it is Seymour who introduces Zen-Buddhism to the rest of the family, and it appeals to them for several reasons: firstly, "it is intuitive rather than rational, and the Glasses approach 
life intuitively"; secondly, "it deals with life directly rather than through the formulations of some metaphorical system, and the Glasses distrust theories"; and thirdly, "it is introspective, teaching that the answers to the ultimate questions must be sought within each man himself; introspection appeals to the Glasses' sense of their own independence and importance" (p. 89). It is also interesting to note that some critics find in Holden the image of Buddha: both of them left the world of affluence and comfort and roamed in the world in search of enlightenment.

In searching for the causes and implications of Salinger's silence, then, it would be rewarding to review his life and works in terms of Vedantic philosophy. As Pattanaik (2006) explains the Vedantic way of life ... visualized two principal modes of living: the life of the householder and the life of the sannyasin [the monk]. While the former led a civic life, the latter devoted his life completely to the prayer of God (p. 203).

He proceeds to explain that though "both ways of life had their different state of perfection", the householder can reach perfection by dedicating "all the fruits of human action to God", while the sannyasin reaches perfection by renouncing "all human action except those for the greater benefit of the world and self-realization" (p. 203). Zooey and Franny, respectively are representatives of these two aspects in Salinger's stories.

The process of the quest in Vedantic philosophy begins with a general dissatisfaction with the existing order of sensual and visual pursuits, goes through different stages of intensification like the intellectual awareness of alternative modes, interiorization and meditation upon that true knowledge and simultaneous withdrawal from the mundane trappings of outward other directed life (Pattanaik, 1998, p. 215).

The parable of the bananafish, which is central to "A Perfect Day for Bananafish", is illuminating in this context. Seymour Glass describes the "peculiar" and "tragic life" of this imaginary fish -obviously a metaphor for the greedy human being-in this way:

They swim into a hole where there's a lot of bananas. They're very ordinary-looking fish when they swim in. but once they get in, they behave like pigs. Why, I've known some bananafish to swim into a banana hole and eat as many as seventy-eight bananas.... Naturally, after that they're so fat they can't get out of the hole again. Can't fit through the door (Salinger, 1964, p. 20). 
Seymour, seemingly tired of all the bananas around, escapes from the hole by killing himself at the end of the story. Another good example is Buddy Glass who appears as another guru for the family after Seymour, and who lives a solitary life in a cottage outside the city. Not only his voluntary seclusion, but also his voice, his style of narration and his accuracy of observation are the grounds on which many critics have equated him with Salinger himself.

Salinger, to take the argument further, is aware of the gap between the secular and spiritual aspects of life in the everyday modern life, and is also aware of the role of art and the artist in filling this gap. As Harper (1967) suggests, Salinger, like many of his contemporaries, is in search of "a clean, well-lighted place in the midst of nada [which is] a vast, incomprehensible flux" (pp. 193-194). It is notable that many of Salinger's characters are "artists", and find boundless consolation and enlightenment in their art: Seymour Glass writes beautiful Haiku-like poems; Buddy is a writer; and Zooey is an actor; Franny, an actress; and the siblings of the Caulfield family are all, in some way or another, writers.

But still there is another feature in Vedantic philosophy which appears paradoxical to the role of the art: the importance of silence. The process of quest, Pattanaik (1998) states, "culminates in the realization of the ultimate silent blissful state of Samadhi" (p. 215). Therefore,

silence is an important ingredient of such a spiritual discipline -as a sign of withdrawal from the whirlwind of material activity that fattens ego, of a quest for an awareness beyond the immediate and peripheral sense apprehensions and possibly of procession of a higher awareness which can only be transmitted to the initiated and may get trivialized by the everyday insincere use of the word (p. 204).

Salinger, in very few interviews after his reclusion, always insisted that "writing was what was important to him -and to be left alone so that he could write" (Eppes, 1981, p. 37), but at the same time, that "he had no plans to publish" (p. 37). Salinger's reluctance to publish his works, thus, can be interpreted as a way to consolidate the two paradoxical elements of his philosophy: he still wrote for consolation and enlightenment, but he wrote for himself and did not intend to publish them. Actually, he believed that publishing is "a vicious, vicious thing" and that there is "a certain peace in not publishing" (p. 37), especially when it comes to mean selling one's 
art. Salinger's attitude towards publishing is not unprecedented in his characters: neither Seymour nor Buddy have the slightest intentions of publishing their works; and Holden regards his brother's going to Hollywood as equal to prostitution because in his view it means selling his art.

Scrutinized in this light, Salinger's unwillingness to publish his stories-which in a way means to sell them-is an explicit manifestation of his criticism towards the dominance of materiality in American life. He was conscious of the conspiracy of the mass media and the marketplace, and as Pattanaik (1998) concludes, "in such a context Salinger's own act of publishing becomes a paradoxical stance in the sense that it conforms to the very marketing, profit oriented society against which some of his characters rebel so often" (p. 208). Salinger's stories, like many of his contemporaries', are replete with the protest against the inauthentic, moneyoriented mentality of the people of American cities. Thus, it is no wonder that he not only refused to live in such an environment and preferred to embrace his solitude in the countryside, but also refuted any activity that confirmed the competitive, egocentric and materialistic attitude of urban life.

Salinger had a lot of difficulties defending his privacy. Only once he allowed Hollywood to adapt one of his short stories, Uncle Wiggily in Connecticut, for motion pictures. But the film entitled My Foolish Heart was so trite and melodramatic that he practically shut his door on film producers afterwards. In 1987, he had to bring a lawsuit against Hamilton (1986) who had made unauthorized use of his letters of 1939-1961 in his biography, J. D. Salinger: A Writing Life. Two other shocks came to him from Joyce Maynard's memoir of her time with Salinger, At Home in the World, in 1998, and from his own daughter, Margaret, who published her memoir of her father in Dream Catcher in 2000. Anyhow, while Holden is becoming more and more discovered-and uncovered- in American literature by both critics and common readers, Salinger was becoming more and more wrapped in mystery. Nobody wants to believe the silence of one of the greatest story-tellers of our time, but everybody agrees that his existing works secure him a prominent place in the literature of the $20^{\text {th }}$ century. 


\section{CATCHER CRITICISM: A SOCIAL HISTORY}

The publication of The Catcher in the Rye was not initially a literary event in 1951 and very few, not even Salinger himself, predicted its later success. The novel sold steadily, though, and broadened its range of readership considerably with its appearance in cheaper paperback edition. The atmosphere of the era was also conducive to the success of the novel. It was a time of burgeoning youth culture, the nonconformist Beat writing, political activism and social right movements. Before long, the prestigious place of Catcher in the setting was undeniable.

Graham (2007) documents that "Catcher received around 200 reviews when it was published, most of them very brief" (p. 40), and most of them favorable. "Reviews tended to focus on issues of form, particularly Salinger's creation of a unique voice for Holden and on the social implications of the novel" (p. 37).

The first wave of academic criticism toward Catcher appeared in the middle of the 1950s and continued up to the 1960s. Heiserman and Miller's essay in 1956 was the first academic appraisal of the novel. They established the novel's prominence by placing it in two respectable traditions of Western literature: the European tradition of quest narrative as exemplified by Homer's The Odyssey; and the American literary heritage of Cooper, Twain and Faulkner, among many others, who seem "fascinated with the outcast, the person who defies tradition in order to arrive at some pristine knowledge, some personal integrity" (Salzman, 1993, p. 8). This analogy set the tone for later criticism of the 50s and 60s, as many of the critics furthered the comparison of Catcher with Huckleberry Finn. Kaplan (1956) mentions the similarities between the two novels "in terms of the first person narrative technique, the colloquial language employed, the nonconformity of both protagonists, the journey both undertake and most of all the moral quality of the novels", and believes that both novels "deal obliquely and poetically with a major theme in American life, past and present -the right of the nonconformist to assert his nonconformity" (Graham, 2007, p. 42). Gwynn and Blotner (1958) predicted in their book, The Fiction of J. D. Salinger: "It is not unconceivable that some day Holden Caulfield may be as well known an American boy as Huck Finn" (Graham, 2007, p. 40).

These comparisons between Catcher and Huckleberry Finn - the best-loved novel in American literature - and later on with other canonical 
works like The Great Gatsby, Moby Dick and even Eliot's The Waste Land place the novel in an important and respectable literary tradition. This canonization of the novel had some opponents too. Steiner (1959) made an outcry that these comparisons are "high praise for any modern novel" (Graham, 2007, p. 48), and that Catcher was not worth that praise.

There were also some critics who followed the linguistic and structuralist vogue of the time, and focused on the language and structure of the novel. Castello (1959), Strauch (1961) are two of the best amongst these criticisms.

Soon after its publication Catcher was turned into a must-read novel for the young generation of America. "University students played a significant role in spreading the word to their peers about the importance of the novel" (Graham, 2007, p. 40). This increasing range of readership among young people led to one of the most interesting phenomena in the history of the novel: its censorship. As Whitfield (2002) argues, "The Catcher in the Rye has even taken on an iconic significance precisely because it is reviled as well as revered" (p. 580), as controversies over the appropriateness of the novel for the youth appeared, and so did requests of parents and authorities to ban the novel from school libraries and curricula. Salzman (1993) reports that "the novel has been banned, often enough by 1973 to be mentioned in the American School Board Journal as 'the most widely censored book in the U.S."' (p. 15). It is notable that, as Steinle (2000) observes, in a decade later Catcher "had the dubious distinction of being at once the most frequently censored book across the nation and the second-most frequently taught novel in public high schools" (Whitfield, 1997, p. 574).

The motives for banning the novel have been generally grouped into two main categories: political anxiety and moralistic orthodoxy. The Cold War discourse of the 50s in the U.S. emphasized conformity and agreement in the face of the ideologically-constructed "red menace" of the communist USSR. But on the contrary, "the American character of Catcher", as Medovoi (1997) states, "seemed more likely to reinject a sense of rebelliousness into the adolescent identity of young Americans" (p. 272). Holden's nonconformist anti-war and anti-capitalistic stance was not something to be ignored by the dominant discourse of the time, and rather paradoxically, as misunderstanding tends to be a special feature of any ideological reading, he was labeled communist by the liberals, and was called liberal by the communists. He was also condemned for refuting the 
idea of American Dream which was greatly supported at the time. Whitfield (2002) observes that "Salinger's novel may thus also be about history veering out of control, about the abyss into which parents could no longer prevent their offspring from staring, about the impotence to which a can-do people was unaccustomed" (p. 593).

Moralistic anxiety over the contents of the novel -especially Holden's language and his contact with a prostitute- and their effects on the youth was no less hostile than the political anxiety. Morris Longstreth, a reviewer in The Christian Science Monitor, was probably the first to voice this anxiety in 1951. He wrote that the novel "is not fit for children to read"; that its central character is "preposterous, profane, and pathetic beyond belief"; and that too many young readers might even want to emulate Holden (as quoted. in Whitfield, 1997, p. 591). The hostility heightened with the publication of the novel in paperback, for as Whitfield (1997) reports, the novel "was offered as pulp fiction, a genre that beckoned with promises of illicit pleasure", and the cover was illustrated with the picture of a prostitute standing beside Holden (p. 591). The cover shows the dangers of misreading and misunderstanding of the novel. It was so offensive to Salinger himself that it prompted him to move to Bantam and prefer simple cover for later editions.

Two other incidents in later decades exemplify the deep impact of Catcher on its common readers. In December 1980, Mark David Chapman murdered John Lennon, one of the Beatles, in a street in New York, and then began re-reading Catcher on the crime scene. Even when he was being sentenced, he insisted that "the reading of that book would be his defense", and started reciting a part of the novel where Holden expresses to Phoebe his wish to become a catcher in the rye (Whitfield, 2002, pp. 356357). A few years later, John Hinkley, Jr. tried to assassinate President Reagan, and as Whitfield (2002) records, said in his defense in the court: "If you want my defense all you have to do is read The Catcher in the Rye. It seemed to be time to read it again" (p. 357). In spite of all these controversies and perpetual attempts to ban Catcher, the novel continues to sell by nearly half a million a year.

The 1970s and 1980s witnessed the dominance of psychoanalytic and Marxist theories in Catcher criticism. Brian Way's essay of 1962 broke new grounds by proposing that adolescent sexuality was the central issue of the novel. His argument found many disciples in an era in which questions of sexuality and gender, masculinity and femininity, and the role of 
different sexes in the social structure dominated a great part of intellectual debates. Later psychoanalyst critics inspected the novel for implications of adolescent sexual anxieties, or of dissenter and queer sexual traits like homosexuality, pedophilia and incest.

On the other hand, now that the Cold War discourse had lost its impetus in the U.S., Marxist criticism began to flourish. Carol and Richard Ohmann's essay in autumn 1976 was a groundbreaking Marxist criticism of the novel. Ohmanns (1976) condemned previous critics for dissociating Catcher from it context, and tried to restore the novel to its specific historical moment (the early 1950s) and its specific place (New York City, America), and its specific social status (upper-middle-class). Two seasons later, Miller (1977) who was one of the prominent "critics" of Ohmanns' (1976) title, responded that "to see Holden's malaise of spirit solely or even mainly caused by the evils of a capitalistic society is surely myopic" (p. 601), and then he asked whether Ohmanns were not trying to "carry Holden out of baffling, muddled history into a tidy and clear-cut ideology?" (p. 603) A few months later, Ohmanns (1977) responded again that Miller's perspective is limited and it "implies a reading of history, and that reading amounts to a denial that history happens" (Graham, 2007, p. 54). "So Catcher, the Ohmanns claim, is obviously a product of the concerns of its moment because Holden's anxieties about sex, death, injustice and so on 'are embedded in his full experience of society"' (p. 54). "The exchange between the Ohmanns and James E. Miller, Jr.", as Salzman (1993) asserts, "was a high point of Salinger criticism in the 1970s..." (p. 14).

The trend of Salinger criticism has turned since the 1990s towards Cultural Studies. Now that there can be no doubt in the importance of Catcher as a canonical work in American literature and as a must-read book among a vast range of readership around the world, critics tend to study the novel in terms of its cultural and social contributions.

\section{REFERENCES}

Alexander, P. (2000). Theft, rumor, and innuendo: Excerpt from Salinger: A biography. In C. Crawford (2006) (Ed.). If you really want to hear about it: Writers on J. D. Salinger and his works (pp. 183-191). New York: Thunder's Mouth Press. 
Batchelor, J. C. (1976, April 22-28). Thomas Pynchon is not Thomas Pynchon: or, this is the end of the plot which has no name. Soho Weekly News, pp. 15-17, 21-35.

Costello, D. P. (1959). The Language of The Catcher in the Rye. American Speech, 34 (3), 172-182.

Curry, R. R. (2007). Holden Caulfield is not a person of colour. In S. Graham (Ed.), J. D. Salinger's The Catcher in the Rye (pp. 77-88). London: Routledge.

Eppes, B. (1981). What I did last summer. In C. Crawford (2006) (Ed.), If you really want to hear about it: Writers on J. D. Salinger and his works (pp. 25-42). New York: Thunder's Mouth Press.

French, W. (1970). The age of Salinger. In W. French (Ed.), The fifties: Fiction, poetry, drama. In Contemporary Literary Criticism, 12, 514-516.

Graham, S. (2007). J. D. Salinger's The Catcher in the Rye. London: Routledge.

Gwynn, F. L.,. \& Blotner, J. L. (1958). The fiction of J .D. Salinger. Pittsburgh: The University of Pittsburgh Press.

Harper, H. M. Jr. (1967). Desperate faith: A study of Bellow, Salinger, Mailer, Baldwin and Updike. Chapel Hill: The University of North Carolina Press.

Hamilton, I. (1986). J. D. Salinger: A writing life. New York: Random House.

Hassan, I. H. (1982). The dismemberment of orpheus: Toward a postmodern literature. Wisconsin: The University of Wisconsin Press.

Havermann, E. (1961). The search for the mysterious J. D. Salinger. In C. Crawford (2006). (Ed.), If you really want to hear about it: Writers on J. D. Salinger and his works (pp. 5-24). New York: Thunder's Mouth Press.

Heiserman, A., \& Miller, J. E. Jr. (1956). J. D. Salinger: Some Crazy Cliff. Western Humanities Review, $X(2), 129-137$.

Kaplan, C. (1956). Holden and huck: The odysseys of youth. College English, 18(2), 79-80.

Medovoi, L. (1997). Democracy, capitalism, and American literature: The cold war construction of J. D. Salinger's Paperback Hero. In J. Foreman (Ed.), The other fifties: Interrogating midcentury American icons. Urbana, Illinois: University of Illinois Press.

Menand, L. (2001). Holden at fifty: The catcher in the rye and what it spawned. In C. Crawford (2006) (Ed.), If you really want to hear about it: Writers on J. D. Salinger and his works (pp. 235-245). New York: Thunder's Mouth Press. 
Miller, J. E. Jr. (1977). Catcher in and out of history. Critical Inquiry, 3(3), 599603.

Mondloch, H. (2003). Squalor and redemption [Electronic version]. The World \& I, 18(11), 232 - 241.

Morrill, S. (2006). A brief biography of J. D. Salinger. In C. Crawford (Ed.), If you really want to hear about it: Writers on J. D. Salinger and his works (pp. 161-181). New York: Thunder's Mouth Press.

Ohmann, C., \& Ohmann, R. (1976). Reviewers, critics, and The Catcher in the Rye. Critical Inquiry, 3(1), 15-37.

Ohmann, C., \& Ohmann, R. (1977). Universals and the historically particular. Critical Inquiry, 3(4), 773-777.

Pattanaik, D. R. (1998). The holy refusal: A Vedantic interpretation of J. D. Salinger's Silence. In C. Crawford (Ed.), If you really want to hear about it: Writers on J. D. Salinger and his works (pp. 199-217). New York: Thunder's Mouth Press.

Salinger, J. D. (1958). The catcher in the rye. London: Hamish Hamilton.

Salinger, J. D. (1962). Franny and Zooey. London: Heineman.

Salinger, J. D. (1964). For Esmé -with love and squalor, and other stories. London: Hamish Hamilton.

Salinger, J. D. (1965). Raise high the roof beam, carpenters, and seymour: An introduction. New York: Bantam Books.

Salinger, M. A. (2000). Dream catcher: A memoir. New York: Washington Square Press.

Salzman, J. (1993) (Ed.). New essays on the catcher in the rye. Cambridge: Cambridge University Press.

Steiner, G. (1959). The Salinger Industry. The Nation, 189, pp. 360-363.

Steinle, P. H. (2000). In cold fear: The catcher in the rye censorship controversies and postwar American character. Ohio: Ohio State University.

Strauch, C. F. (1961). Kings in the back row: Meaning through structure, A reading of J. D. Salinger's The Catcher in the Rye, Wisconsin Studies in Contemporary Literature, 2(1), 5-30.

Way, B. (1962). Franny and Zooey and J. D. Salinger. New Left Review, I, 15. 
Whitfield, S. J. (1997). Cherished and cursed: Toward a social history of The Catcher in the Rye [Electronic version]. The New England Quarterly, 70(4), 567-601.

Whitfield, S. J. (2002). Raise high the bookshelves, censors! [Electronic version]. The Virginia Quarterly Review, 78(2), 356-361. 